Dewi Sartika

\title{
Determinan Purchase Intention dan Implikasinya Terhadap Purchase Decision Sepatu Non Original (KW) Pada Mahasiswa Perguruan Tinggi di Kota Samarinda
}

\author{
Dewi Sartika \\ Universitas Muhammadiyah Kalimantan Timur, Samarinda
}

Email: ds106@umkt.ac.id

\begin{abstract}
Abstrak
Penelitian in meneliti determinan perilaku minat membeli dan implikasinya terhadap keputusan pembelian sepatu non original $(\mathrm{KW})$ pada mahasiswa perguruan tinggi di Kota Samarinda. Setelah memperoleh 224 responden yang berpartisipasi dalam penelitian yaitu mahasiswa perguruan tinggi di Kota Samarinda yang pernah membeli sepatu non original (KW) yang kemudian dianalisis secara kuantitatif menggunakan SEM (Structural Equation Model). Hasil penelitian menunjukkan bahwa delapan hipotesis yang diajukan diterima yaitu Subjective Norms berpengaruh signifikan terhadap Attitude toward Purchasing, Perceived Risk berpengaruh signifikan terhadap Attitude toward Purchasing, Price berpengaruh signifikan terhadap Attitude toward Purchasing, Subjective Norms berpengaruh signifikan terhadap Purchase Intention, Perceived Risk berpengaruh signifikan terhadap Purchase Intention, Price berpengaruh signifikan terhadap Purchase Intention, Attitude toward Purchasing berpengaruh signifikan terhadap Purchase Intention dan Purchase Intention berpengaruh signifikan terhadap Purchase Decision. Hasil temuan ini mendukung teori dan penelitian sebelumnya yang menjadi acuan peneliti.
\end{abstract}

Keywords: Subjective Norms, Perceived Risk. Price, Attitude toward Purchasing, Purchase Intention, Purchase Decision, Sepatu Non Original (KW), Kota Samarinda

\section{Pendahuluan}

Counterfeiting atau peniruan adalah tindakan pelanggaran atau penyalahan terhadap hak legal dari suatu organisasi yang memiliki intellectual property. Produk tiruan biasa dikenal dengan produk KW. Produk ini biasanya meniru produk original yang memiliki brand (nama) yang sudah sangat terkenal, atau pada produk luxury dengan harganya yang sangat mahal. Kualitas produk tiruan terus membaik selama beberapa tahun terakhir daripada merek aslinya. Ini disebabkan sebagian besar produk merek asli mengurangi biaya produksi untuk outsourcing manufaktur. Beberapa pabrik mulai beralih untuk memproduksi barang tiruan karena dengan menjual produk tiruan mereka mendapatkan margin yang cukup tinggi. Dengan membaiknya kualitas produk tiruan membuat konsumen tertarik untuk melakukan pembelian terhadap produk tiruan dari barang-barang bermerek mewah. Dengan membeli produk tiruan bermerek mewah konsumen mendapatkan prestise dari produk bermerek tanpa membayar mahal (Grossman dan Shapiro, 1998).

Memperdangangkan barang tiruan dapat merugikan pihak-pihak tertentu seperti pemegang lisensi merek dan negara dari sektor cukai. Menurut Kementerian Perindustrian Republik Indonesia menyebutkan bahwa berdasarkan hasil survei Masyarakat Indonesia Anti 
Pemalsuan (MIAP) mengenai produk palsu terhadap ekonomi nasional selama 2014 sudah tembus mencapai Rp 65,1 triliun. Berdasarkan hasil studi Masyarakat Indonesia Anti Pemalsuan (MIAP). Sekeretaris Jenderal MIAP Justisiari P. Kusumah mengatakan kerugian itu meningkat dibandingkan hasil survei MIAP tahun 2010 yang memperkirakan kerugian perekonomian terkait Produk Domestik Bruto (PDB) sebesar Rp43.2 triliun. Selang waktu 5 tahun kerugian negara akibat maraknya peredaran produk tiruan yang masuk dari luar negeri tercatat meningkat hampir 1,5 kali lipat.

Data dari hasil survei atau studi Dampak Pemalsuan Terhadap Perekonomian Indonesia 2015 Jakarta menyimpulkan bahwa Indonesia sebagai negara tujuan masuknya produkproduk tiruan dari luar negeri sudah termasuk sangat mengkawatirkan. Studi menyebutkan 12 komoditas yang terdiri atas pemalsuan produk makanan dan minuman merugikan negara sebanyak Rp 155.147.000.000 sedangkan untuk kategori komoditas pakaian dan barang dari kulit menyebabkan kerugian Rp 191.993.000.000. Kemudian, komoditas obat-obatan dan kosmetika mengakibatkan kerugian Rp 42.079.000.000. Sedangkan, komoditas software dan tinta menyebabkan kerugian dari segi pajak sebesar Rp 35.638.000.000. Negara juga menderita kerugian akibat kehilangan kesempatan kerja untuk rakyat Indonesia, yakni Rp 3.395.887.000.000.

Walaupun produk tiruan kerap menimbulkan masalah dan pertentangan, namun di level konsumen merasa bahwa bahwa kehadiran produk tiruan justru menguntungkan karena mereka memiliki alternative untuk memiliki produk bermerek terkenal dan harganya pasti mahal dengan merek yang sama dengan harga yang jauh lebih murah. Produk tiruan masih tetap menjadi pilihan bagi berbagai konsumen termasuk Sepatu Non Original (KW) dengan merek terkenal terkhusus pada mahasiswa perguruan tinggi di Kota Samarinda yang pola belanjanya adalah banyak dilandasi atas motif emosional atau motif gengsi dengan beberapa alasan yang mendasari perilaku pembelian produk palsu tersebut. Kasus produk tiruan kini sudah menjadi perhatian di dunia internasional, dimana hampir di seluruh negara dapat ditemukan produk-produk tiruan.

Menurut informasi awal yang peneliti dapatkan dan ternayata didukung oleh hasil penelitian empiris bahwa sikap konsumen yang membeli Sepatu Non Original (KW) banyak dikarenakan harga sepatu merek aslinya memang terlalu mahal dan konsumen merasa tidak bisa menjangkau untuk membeli sepatu original walaupun mereka sadar bahwa membeli Sepatu non original (KW) terkadang juga berpotensi mengandung risiko kualitas produk atau desainya tidak sama dengan yang dikehendaki oleh konsumen. Atas pertimbangan tersebut maka penelitian ini akan memfokuskan meneliti faktor-faktor atau variabel-variabel yang sekiranya berpotensi mempengaruhi minat membeli sepatu non original (KW).

\section{Landasan Teori}

\section{Subjective Norms}

Ajzen (2005) mengatakan norma subjektif merupakan fungsi yang didasarkan oleh belief yang disebut normative belief, yaitu belief mengenai kesetujuan dan atau ketidaksetujuan yang berasal dari referent atau orang dan kelompok yang berpengaruh bagi individu (significant others) seperti orang tua, pasangan, teman dekat, rekan kerja atau lainnya terhadap suatu perilaku. Fishbein dan Ajzen (1991:45) mendefinisikan Subjective Norms sebagai persepsi individu tentang apakah orang penting bagi individu berpikir perilaku harus dilakukan. Kontribusi pendapat dari setiap rujukan yang diberikan dibobot dengan motivasi bahwa seorang individu harus mematuhi keinginan rujukan itu. Subjective Norms adalah faktor sosial yang mengacu pada tekanan sosial yang dimana seseorang akan merasa untuk melakukan sebuah perilaku tertentu atau tidak. Subjective Norms berkaitan dengan persepsi terhadap dari tekanan sosial yang menekankan kepercayaan normative dari individu 
atau kelompok sehingga individu termotivasi untuk menunjukan perilaku yang disetujui oleh kelompok. Sebagai sesuatu yang mewakili harapan tiap orang yang saling berkaitan satu sama lain dan terdiri dari keyakinan normatif dan motivasi untuk mematuhi apa yang mereka yakini. Menurut Theory of Reasoned Action ( TRA ), sikap individu dan norma subjektif mempengaruhi niat perilaku yang dapat memperkirakan perilaku yang sebenarnya. Norma subjektif (Subjective Norms) dibentuk oleh :

a. Normative Belief (keyakinan normatif), yaitu keyakinan terhadap orang lain (kelompok acuan atau referensi) bahwa mereka berpikir subjek seharusnya atau tidak melakukan suatu perilaku atau keyakinan normatif tentang harapan orang lain (kelompok acuan) terhadap dirinya mengenai apa yang seharusnya dilakukan.

b. Motivation to Comply (motivasi mematuhi), yaitu motivasi yang sejalan dengan keyakinan normatif atau motivasi yang sejalan dengan orang yang menjadi kelompok acuan.

Subjective Norms didefinisikan sebagai persepsi individu tentang tekanan sosial untuk melakukan atau tidak melakukan suatu perilaku Ajzen (2005). Subjective Norms ditentukan oleh kombinasi antara normative belief individu dan motivation to comply. Biasanya semakin individu mempersepsikan bahwa social referent yang mereka miliki mendukung mereka untuk melakukan suatu perilaku maka individu tersebut akan cenderung merasakan tekanan sosial untuk memunculkan perilaku tersebut. Dan sebaliknya semakin individu mempersepsikan bahwa social referent yang mereka miliki tidak menyetujui suatu perilaku maka individu cenderung merasakan tekanan sosial untuk tidak melakukan perilaku tersebut. Ajzen (1991) dan Sharma dan Chan (2016) mengukur Subjective Norms dapat dengan empat indikator yaitu Approve a Decision (Menyetujui Keputusan), Should Buy (Keharusan Membeli), No One Will Mind (Tidak ada yang keberatan) dan Smart Decision (Keputusan yang Bijak).

\section{Perceived Risk}

Pengertian persepsi resiko menurut Bauer (1967) dijelaskan sebagai perasaan ketidakpastian mengenai kemungkinan munculnya konsekuensi negatif ketika menggunakan sebuah produk atau jasa. Persepsi resiko menyangkut pada konsekuensi yang sebenarnya tidak diinginkan, bahwa konsumen ingin menghindari munculnya resiko ketika mereka membeli atau menggunakan suatu produk. Ada beberapa macam konsekuensi negatif yang mungkin terjadi. Bisa saja beberapa konsumen ragu tentang resiko pada fisik dari produk yang dikonsumsi. Ada pula beberapa konsekuensi yang tidak menyenangkan lainnya yang termasuk yaitu resiko finansial, resiko pada fungsi dan resiko psikologi. Persepsi resiko memuat tentang pengetahuan konsumen atau kepercayaan tentang konsekuensi yang tidak baik, termasuk tanggapan negatif terhadap perasaan yang terkait dengan konsekuensi yang tidak menyenangkan (evaluasi yang tidak menyenangkan, perasaan yang buruk dan emosi yang negatif. Peter dan Olson (2012:74) mendefinisikan persepsi resiko sebagai konsekuensi yang tidak diharapkan yang ingin dihindari konsumen saat membeli dan menggunakan produk. Dalam penelitian ini indikator Perceived Risk diadopsi dari Dowling dan Staelin (1994) dan Jacoby dan Kaplan (1972) yang terdiri dari High Risk (Beresiko tinggi), Damage Probability (Peluang adanya kerusakan), Bad Decision (Keputusan yang buruk), Social Risk (Resiko sosial), Psychological Risk (Resiko Psikis) dan Un-appropriated (Ketidaksesuaian).

\section{Price}

Harga merupakan salah satu bagian yang sangat penting dalam pemasaran suatu produk karena harga adalah satu dari empat bauran pemasaran / marketing mix (4P = product, Price, place, promotion / produk, harga, distribusi, promosi). Harga adalah suatu nilai tukar dari produk barang maupun jasa yang dinyatakan dalam satuan moneter. 
Machfoedz (2005) mengatakan: penetapan suatu harga dapat dipengaruhi oleh faktor internal yang terdiri dari tujuan perusaan dalam memasarkan produk, strategi yang dipakai oleh perusahaan dalam memasarkan produk, biaya yang dikeluarkan preusahaan untuk memproduksi dan memasarkan produk dan faktor eksternal yang dapat dilihat dari model pasar yang akan dituju produk, persaingan harga dengan produk lain, serta lingkungan yang akan menjadi sasaran produk tersebut. Penetapan harga suatu produk atau jasa tergantung dari tujuan perusahaan atau penjual yang memasarkan produk tersebut. Machfoedz (2005) juga berpendapat tujuan dari penetapan suatu harga adalah utuk mencapai target perusaan, mendapatkan laba dari penjualan, meningkatkan serta mengembangkan produksi produk, serta meluaskan target pemasaran. Dalam penelitian ini indikator variabel Price yang digunakan ialah indikator yang diadopsi dari Lichtenstein et al. (1993) dan Huang et al. (2004) yang terdiri dari Higher the Price Higher Quality (Harga tinggi, Kualitas tinggi), Indicator the Quality (Pengukur Kualitas), Pay More For Better Quality (Membayar lebih untuk kualitas terbaik) dan Cheapness (Harga rendah).

\section{Attitude toward Purchasing}

Menurut Ajzen (2005) sikap terhadap perilaku merupakan salah satu faktor penentu terbentuknya intensi. Sikap terhadap perilaku didefinisikan Ajzen (2005) sebagai derajat penilaian positif atau negative individu terhadap perilaku tertentu. Sikap terhadap perilaku ditentukan oleh evaluasi individu mengenai hasil yang ber dengan perilaku dan dengan kekuatan dari kedua hal tersebut. Semakin individu memiliki evaluasi bahwa suatu perilaku akan menghasilkan konsekuensi positif maka individu akan cenderung bersikap favorable terhadap perilaku tersebut. Sikap terhadap perilaku tersebut yang akan mempengaruhi intensi seseorang dalam memunculkan sebuah perilaku. Thurstone mendefinisikan sikap (Attitude) sebagai derajat afek positif atau afek negatif terhadap suatu objek psikologis (dalam Azwar, 2007). Sikap atau Attitude senantiasa diarahkan pada suatu hal, suatu objek. Tidak ada sikap tanpa adanya objek (Gerungan, 2004). Definisi Petty dan Cacioppo secara lengkap mengatakan sikap adalah evaluasi umum yang dibuat manusia terhadap dirinya sendiri, orang lain, objek atau isu-isu (dalam Azwar, 2007). Menurut Fishben dan Ajzen (1991:52), sikap sebagai predisposisi yang dipelajari untuk merespon secara konsisten dalam cara tertentu berkenaan dengan objek tertentu. Variable ini diukur dengan 5 (lima) indikator diadopsi dari penelitian Matos et al. (2007) yang terdiri atas Copy the newest version (Menyalin versi terbaru), Would not mind buying (Tidak masalah untuk membeli), Nothing wrong with purchasing (Tidak ada yang salah dengan melakukan pembelian), Better choice (Pilihan terbaik) dan Purchasing (Pembelian).

\section{Purchase Intention}

Menurut Schiffman dan Kanuk (2010) minat beli dapat menilai kemungkinan dari konsumen yang membeli suatu produk, dan semakin tinggi minat beli maka semakin tinggi pula keinginan konsumen untuk membeli sebuah produk. Lebih lanjut, minat beli dapat dianggap sebagai kesukaan subjektif yang dapat digunakan sebagai media untuk memperkirakan perilaku tertentu pada proses pembelian oleh konsumen. Variable minat beli dapat diukur dengan minat beli, minat untuk mempertimbangkan untuk membeli dan minat untuk merekomendasikan kepada orang lain Assael (1998). Busler (2000) menyatakan bahwa Purchase Intention dapat diukur melalui dimensi likely yakni rencana pembelian konsumen terhadap suatu produk, definitely would mengacu kepada kepastian konsumen dalam suatu produk, dan probable mengacu padakemungkinan konsumen dalam membeli suatu produk. Menurut Engel dkk (2002), Purchase Intention terkait dengan 2 (dua) kategori yaitu kategori pertama Purchase Intention terhadap produk dan merek atau biasa disebut fully planned purchase, kemudian kategori kedua yakni Purchase Intention terhadap kategori produk saja 
atau biasa disebut planned purchase meskipun pilihan terhadap merek dibuat pada saat pembelian (point of sales). Peter dan Olson (2012) mendefinisikan Purchase Intention adalah "based on consumer Attitude toward buying abrand". Sedangkan menurut Kotler dan Keller (2015) definisi Purchase Intention adalah perilaku konsumen terjadi ketika konsumen dirangsang oleh faktor eksternal dan mulai membeli keputusan berdasarkan karakteristik pribadi mereka dan proses pengambilan keputusan. Pada penelitian ini indikator yang digunakan adalah indikator yang diadopsi dari Matos et al. (2007) dan Sharma dan Chan (2016) yang terdiri dari No Hesitation (Tidak merasa ragu), Choice (Pilihan), Genuine Product too Expensive (Produk asli terlalu mahal), Specific Brand (Brand tertentu) dan Will Recommended (Akan merekomendasikan).

\section{Purchase Decision}

Menurut Amirullah (2002:62) "Keputusan pembelian dapat didefinisikan sebagai suatu proses dimana konsumen melakukan penilaian terhadap berbagai alternatif pilihan, dan memilih salah satu atau lebih alternatif yang diperlukan berdasarkan pertimbanganpertimbangan tertentu". Schiffman dan Kanuk (2010:485) menjelaskan di dalam bukunya bahwa pengambilan keputusan pembelian merupakan suatu proses evaluasi yang dilakukan konsumen dalam memecahkan masalah yang dihadapi dalam pemilihan produk, keputusan adalah dua seleksi terhadap dua pilihan alternatif atau lebih. Kemudian Kotler dan Armstrong (2018:183) mendefinisikan bahwa keputusan pembelian adalah keputusan konsumen untuk membeli mengenai merek mana yang akan dibelinya. Dari ketiga definisi menurut para ahli terkait keputusan pembelian maka dapat diketahui bahwa keputusan pembelian merupakan penilaian konsumen terhadap alternatif produk, mengenai penetapan pilihan merek yang disukai berdasarkan pertimbangan-pertimbangan tertentu. Pada penelitian ini indikator yang digunakan adalah indikator yang diadopsi dari Kotler dan Keller (2015) serta Madjid (2014) yang terdiri dari Menetapkan pilihan terhadap produk, Keyakinan untuk membeli, Purchase Frequency (Frekuensi Pembelian) dan Overall satisfaction (Kepuasan Secara Keseluruhan).

\section{Model Konseptual Penelitian}

Model penelitian dan kerangka kerja konsep penelitian dapat dilihat pada diagram berikut:

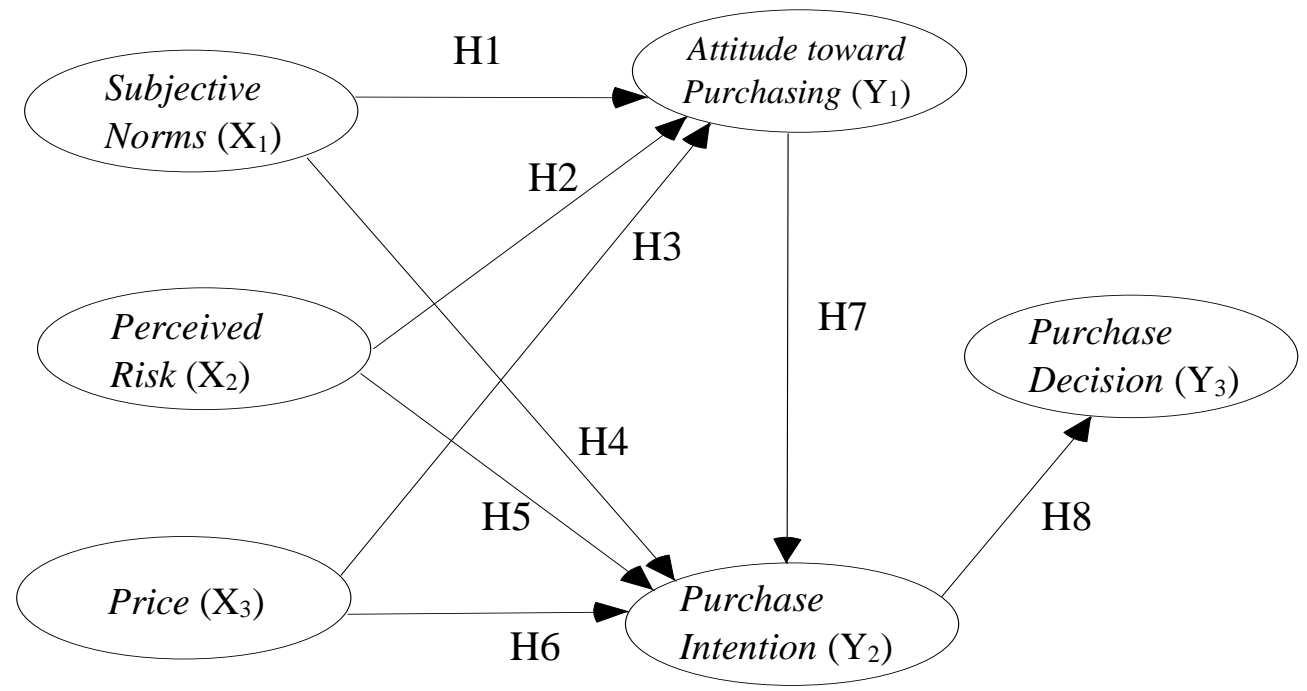

Gambar 1. Model Penelitian 


\section{Hipotesis Penelitian}

Berdasarkan rumusan masalah, landasan teoritis, baik kajian teoritis maupun empiris, kerangka konseptual kemudian mengajukan hipotesis penelitian sebagai berikut:

$\boldsymbol{H}_{1}$ : Subjective Norms berpengaruh signifikan terhadap Attitude toward Purchasing Sepatu Non Original (KW) pada mahasiswa Perguruan Tinggi di Kota Samarinda.

$\boldsymbol{H}_{2}$ : Perceived Risk berpengaruh signifikan terhadap Attitude toward Purchasing Sepatu Non Original (KW) pada mahasiswa Perguruan Tinggi di Kota Samarinda.

$\boldsymbol{H}_{3}$ : Price berpengaruh signifikan terhadap Attitude toward Purchasing Sepatu Non Original (KW) pada mahasiswa Perguruan Tinggi di Kota Samarinda.

$H_{4}$ : Subjective Norms berpengaruh signifikan terhadap Purchase Intention Sepatu Non Original (KW) pada mahasiswa Perguruan Tinggi di Kota Samarinda.

H5: Perceived Risk berpengaruh signifikan terhadap Purchase Intention Sepatu Non Original (KW) pada mahasiswa Perguruan Tinggi di Kota Samarinda.

$\boldsymbol{H}_{6}$ : Price berpengaruh signifikan terhadap Purchase Intention Sepatu Non Original (KW) pada mahasiswa Perguruan Tinggi di Kota Samarinda.

H$_{7}$ : Attitude toward Purchasing berpengaruh signifikan terhadap Purchase Intention Sepatu Non Original (KW) pada mahasiswa Perguruan Tinggi di Kota Samarinda.

$\boldsymbol{H}_{8}:$ Purchase Intention berpengaruh signifikan terhadap Purchase Decision Sepatu Non Original (KW) pada mahasiswa Perguruan Tinggi di Kota Samarinda.

\section{Metodelogi penelitian}

\section{Definisi Operasional}

Tabel 1. Definisi Opersional Variabel dan Indikator

\begin{tabular}{|c|l|}
\hline Variabel & \multicolumn{1}{|c|}{ Indikator } \\
\hline Subjective Norms $\left(\mathrm{X}_{1}\right)$ & SN1 High Risk (Beresiko tinggi). Ketika membeli atau \\
menggunakan suatu produk ada kemungkinan untuk \\
Subjective Norms didefinisikan & munculnya resiko yang sangat tinggi. \\
tanggapan mahasiswa di & SN2 Damage Probability (Peluang adanya kerusakan). \\
Perguruan Tinggi di Kota & Persepsi seseorang ketika membeli atau menggunakan \\
Samarinda tentang perasaan & suatu produk akan terjadi kerusakan. \\
mereka apabila membeli atau & SN3 Bad Decision (Keputusan yang buruk). Salah satu \\
menggunakan Sepatu Non & resiko dapat muncul ketika seseorang merasa salah dalam \\
Original (KW). Karena norma & membuat keputusan (keputusan yang buruk). \\
yang belaku disuatu tempat & SN4 Social Risk (Resiko sosial). Resiko yang muncul \\
belum tentu berlaku di tempat & ketika berada diantara lingkungan sosial ketika apa yang \\
lain. Adanya norma-norma yang & kita lakukan tidak sesuai dengan adat atau kebiasaan di \\
berlaku ditiap-tiap kelompok & lingkungan sosial tersebut. \\
akan mendorong seseorang utuk & SN5 Psychological Risk (Resiko Psikis). Resiko yang \\
secara suka rela atau terpaksa & dirasakan seseorang dan berpengaruh pada kepribadian \\
untuk melakukan sesuatu agar & seseorang. \\
dapat diterima di & SN6 Un-appropriated (Ketidaksesuaian). Terjadi karena \\
lingkungannya. & adanya gap atau perbedaan antara antara harapan maupun \\
& janji yang diberikan terhadap kenyataan yang diterima. \\
\hline Perceived Risk (X) $\left.{ }_{2}\right)$ & PR1 High Risk (Beresiko tinggi). Ketika membeli atau \\
Perceived Risk didefinisikan & menggunakan suatu produk ada kemungkinan untuk \\
sebagai tanggapan mahasiswa di & munculnya resiko yang sangat tinggi. \\
\hline
\end{tabular}




\begin{tabular}{|c|c|}
\hline $\begin{array}{l}\text { Perguruan Tinggi di Kota } \\
\text { Samarinda tentang perasaan } \\
\text { mereka apabila membeli atau } \\
\text { menggunakan Sepatu Non } \\
\text { Original (KW). Karena norma } \\
\text { yang belaku disuatu tempat } \\
\text { belum tentu berlaku di tempat } \\
\text { lain. Adanya norma-norma yang } \\
\text { berlaku ditiap-tiap kelompok } \\
\text { akan mendorong seseorang utuk } \\
\text { secara suka rela atau terpaksa } \\
\text { untuk melakukan sesuatu agar } \\
\text { dapat diterima di } \\
\text { lingkungannya. }\end{array}$ & $\begin{array}{l}\text { PR2 Damage Probability (Peluang adanya kerusakan). } \\
\text { Persepsi seseorang ketika membeli atau menggunakan } \\
\text { suatu produk akan terjadi kerusakan. } \\
\text { PR3 Bad Decision (Keputusan yang buruk). Salah satu } \\
\text { resiko dapat muncul ketika seseorang merasa salah dalam } \\
\text { membuat keputusan (keputusan yang buruk). } \\
\text { PR4 Social Risk (Resiko sosial). Resiko yang muncul } \\
\text { ketika berada diantara lingkungan sosial ketika apa yang } \\
\text { kita lakukan tidak sesuai dengan adat atau kebiasaan di } \\
\text { lingkungan sosial tersebut. } \\
\text { PR5 Psychological Risk (Resiko Psikis). Resiko yang } \\
\text { dirasakan seseorang dan berpengaruh pada kepribadian } \\
\text { seseorang. } \\
\text { PR6 Un-appropriated (Ketidaksesuaian). Terjadi karena } \\
\text { adanya gap atau perbedaan antara antara harapan maupun } \\
\text { janji yang diberikan terhadap kenyataan yang diterima. }\end{array}$ \\
\hline $\begin{array}{c}\text { Price }\left(\mathrm{X}_{3}\right) \\
\text { Price didefinisikan sebagai } \\
\text { tanggapan mahasiswa di } \\
\text { Perguruan Tinggi di Kota } \\
\text { Samarinda tentang harga } \\
\text { sebagai salah satu pertimbangan } \\
\text { utama dalam memutuskan } \\
\text { membeli Sepatu Non Original } \\
\text { (KW). Karena masyarakat } \\
\text { beranggapan bahwa harga } \\
\text { merupakan cerminan dari rupa, } \\
\text { sehingga masyarakat bisa } \\
\text { mengetahui secara abstrak } \\
\text { kualitas dari sebuah produk dari } \\
\text { melihat harga. }\end{array}$ & $\begin{array}{l}\text { P1 Higher The Price Higher Quality (Harga tinggi, } \\
\text { Kualitas tinggi). Semakin tinggi harga sebuah produk } \\
\text { maka seseorang mempersepsikan bahwa akan semakin } \\
\text { tinggi pula kualitas produk tersebut. } \\
\text { P2 Indicator The Quality (Pengukur Kualitas) Harga } \\
\text { merupakan alat ukur dari kualitas sebuh produk. } \\
\text { P3 Pay More For Better Quality (Membayar lebih untuk } \\
\text { kualitas terbaik) Untuk mendapatkan produk dengan } \\
\text { kualitas yang terbaik maka seseorang akan rela untuk } \\
\text { membayar dengan harga yang lebih mahal. } \\
\text { P4 Cheapness (Harga rendah). Menetapkan harga yang } \\
\text { rendah atau murah merupakan strategi untuk } \\
\text { memenangkan pasar, karena kebanyakan konsumen atau } \\
\text { pembeli memilih produk karena harga rendah }\end{array}$ \\
\hline $\begin{array}{c}\text { Attitude toward Purchasing }\left(\mathrm{Y}_{1}\right) \\
\text { Attitude toward Purchasing } \\
\text { didefinisikan sebagai suatu } \\
\text { anggapan mahasiswa di } \\
\text { Perguruan Tinggi di Kota } \\
\text { Samarinda tentang sikap atau } \\
\text { tindakan seseorang terhadap } \\
\text { pembelian dan penggunaan } \\
\text { produk tiruan yang tercermin } \\
\text { dari rasa kesukaan dan } \\
\text { sebaliknya. }\end{array}$ & $\begin{array}{l}\text { ATP1 No Hesitation (Tidak merasa ragu). Sikap } \\
\text { seseorang yang merasa tidak ragu dalam mengambil } \\
\text { keputusan, menentukan pilihan, dan sebagainya. } \\
\text { ATP2 Choice (Pilihan) Sikap dalam mempertimbangkan } \\
\text { sesuatu yang dianggap sesuai dengan kesukaan, selera dan } \\
\text { sebagainya. } \\
\text { ATP3 Genuine Product too Expensive (Produk asli terlalu } \\
\text { mahal). Kondisi dimana seseorang merasa atau } \\
\text { mempersepsikan bahwa harga produk yang asli memiliki } \\
\text { harga yang sangat mahal atau lebih tinggi karena } \\
\text { membandingkan harga produk tersebut dengan harga } \\
\text { produk tiruannya. } \\
\text { ATP4 Specific Brand (Brand tertentu). Sikap seseorang } \\
\text { yang akan melakukan pembelian barang pada sebuah } \\
\text { brand-brand tertentu. } \\
\text { ATP5 Will Recommended (Akan merekomendasikan). } \\
\text { Sikap seseorang yang akan melakukan rekomendasi } \\
\text { sebauh produk (barang maupun jasa) kepada orang } \\
\text { disekitarnya atau orang lain. }\end{array}$ \\
\hline
\end{tabular}


Purchase Intention $\left(\mathrm{Y}_{2}\right)$

Purchase Intention didefinisikan sebagai tanggapan mahasiswa di

Perguruan Tinggi di Kota

Samarinda tentang minat seseorang untuk melakukan pembelian produk tiruan.
Purchase Decision $\left(\mathrm{Y}_{3}\right)$

Purchase Decision didefinisikan sebagai anggapan mahasiswa di

Perguruan Tinggi di Kota Samarinda tentang keputusan seseorang untuk melakukan pembelian produk tiruan karena munculnya niat pembelian.

PI1 No Hesitation (tidak ragu). Adalah tanggapan mahasiswa di Perguruan Tinggi di Kota Samarinda bahwa mereka tidak merasa ragu untuk melakukan pembelian Sepatu Non Original (KW).

PI2 Choice (pilihan). Adalah tanggapan mahasiswa di Perguruan Tinggi di Kota Samarinda bahwa mereka merasa membeli Sepatu Non Original (KW) merupakan salah satu pilihan agar mendapatkan sepatu versi terbaru atau merek sepatu tertentu dengan harga yang tidak mahal.

PI3 Genuine Product Too Expensive (produk aslinya terlalu mahal). Adalah tanggapan mahasiswa di Perguruan Tinggi di Kota Samarinda bahwa membeli Sepatu Non Original (KW) dengan alasan bahwa produk asliterlalu mahal harganya.

PI4 Specific Brand (merek khusus). Adalah tanggapan mahasiswa di Perguruan Tinggi di Kota Samarinda bahwa mereka membeli Sepatu Non Original (KW) pada merek tertentu karena produk tersebut belum tersedia atau dikarenakan harga sepatu originalnya pada merek tesebut sangat mahal.

PI5 Will Recommended (akan merekomendasi). Adalah tanggapan mahasiswa di Perguruan Tinggi di Kota Samarinda bahwa mereka akan merekomendasikan atau menyarankan kepada orang lain untuk membeli Sepatu Non Original (KW).

PD1 Menetapkan pilihan pada produk. Adalah tanggapan mahasiswa di Perguruan Tinggi di Kota Samarinda bahwa mereka menetapkan pilihannya untuk membeli Sepatu Non Original (KW)an.

PD2 Keyakinan untuk membeli. Adalah tanggapan mahasiswa di Perguruan Tinggi di Kota Samarinda bahwa mereka memiliki keyakinan untuk membeli Sepatu Non Original (KW).

PD3 Purchase Frequency (frekuensi pembelian). Adalah tanggapan mahasiswa di Perguruan Tinggi di Kota Samarinda terhadap seberapa sering membeli Sepatu Non Original (KW).

PD4 Overall satisfaction (kepuasan secara keseluruhan). Adalah tanggapan mahasiswa di Perguruan Tinggi di Kota Samarinda bahwa mereka merasa puas membeli Sepatu Non Original (KW) dengan segala atribut maupun harganya.

Sumber : Dirangkum oleh peneliti, 2021

\section{Desain Penelitian}

Penelitian ini bertujuan untuk mengembangkan dan menemukan dengan bukti menggunakan SEM (Structure Equation Model), maka akan diketahui hubungan dan pengaruh variabel eksogen terhadap variabel endogen yang terimplikasi oleh variabel 
intervening. Data yang digunakan untuk mengukur hubungan korelatif di atas adalah data cross section yang diambil dari responden di perguruan tinggi Kota Samarinda.

\section{Populasi dan Sampel}

Populasi sasaran dalam penelitian ini adalah mahasiswa perguruan tinggi di Kota Samarinda dengan jumlah populasi yang tidak diketahui pasti jumlah populasi sehingga peneliti menggunakan rumus dari Hair at al. (2010) dalam penentuan sampel. Jumlah sampel penelitian ini adalah sebanyak 224 responden yaitu mahasiswa perguruan tinggi di Kota Samarinda.

\section{Prosedur Pengumpulan Data}

Penelitian ini menggunakan metode wawancara langsung kepada responden yang disebarluaskan oleh tim survei yang telah diberi pengetahuan tentang prosedur pengisian kuesioner. Untuk mendapatkan tingkat respons yang diharapkan, hal-hal berikut dilakukan: 1 . Kuesioner dirancang dengan format standar dengan pertanyaan pendek dan jelas, 2. Kuesioner disebar di lingkungan yang terdapat banyak Mahasiswa seperti di kmapus ataupun perpustakaan yang ada di Kota Samarinda. Namun demikian, sebelum semua responden diberikan kuesioner, terlebih dahulu instrumen penelitian diuji validitas dan reliabilitasnya.

\section{Teknik Analisis Data}

Penelitian ini menggunakan pendekatan kuantitatif dalam melakukan analisis data, dan metode analitik digunakan dalam menganalisis data empiris:

\section{1) Analisis statistik deskriptif}

Analisis statistik deskriptif dimaksudkan untuk mengetahui distribusi frekuensi jawaban dari hasil kuesioner. Dengan mengumpulkan data dari hasil jawaban responden kemudian ditabulasi dalam tabel dan dilakukan diskusi deskriptif. Ukuran deskriptif adalah penyediaan angka, baik dalam jumlah responden dan nilai rata-rata jawaban atau persentase responden. Analisis data ini digunakan untuk memberikan gambaran tentang pengaruh Subjective Norms, Perceived Risk, Price, Attitude toward Purchasing, Purchase Intentoion dan Purchase Decision.

\section{2) Analisis Statistik Inferensial: SEM}

Analisis statistik inferensial berfokus pada bidang analisis dan interpretasi data untuk menarik kesimpulan. Analisis ini digunakan untuk menguji hipotesis penelitian yang telah ditentukan dengan menggunakan data sampel yang diperoleh. Metode Statistik Inferensial yang digunakan dalam analisis data penelitian ini adalah Structural Equation Modeling (SEM). Alasan untuk menggunakan SEM, adalah bahwa hubungan sebab akibat yang dirumuskan dalam penelitian ini menggunakan model yang tidak disederhanakan yang berfungsi ganda sebagai kepuasan pelanggan. Jenis hubungan sebab akibat ini membutuhkan analisis yang menjelaskan hubungan secara bersamaan sehingga metode yang digunakan dalam penelitian ini menggunakan SEM.

\section{Pembahasan}

\section{Estimasi Model Pengukuran (Measurement Model)}

Confirmatory factor analysis digunakan untuk mengkonfirmasi faktor-faktor yang dibentuk untuk mendefinisikan sebuah konsep atau konstruk penelitian. Hasil pengukuran terhadap loading factor ditampilkan sebagai berikut:

a. Konstruk Eksogen. Hasil dari confirmatory factor analysis untuk konstruk eksogen 
disajikan seperti tabel di bawah ini:

Tabel 2. Standardized Regression Weights CFA Konstruk Eksogen

\begin{tabular}{|lll|r|}
\hline & & & Estimate \\
\hline X1\#1 & $<---$ & Subjective Norms &, 578 \\
X1\#2 & $<---$ & Subjective Norms &, 501 \\
X1\#3 & $<---$ & Subjective Norms &, 606 \\
X1\#4 & $<---$ & Subjective Norms &, 645 \\
X2\#1 & $<---$ & Perceived Risk &, 370 \\
X2\#2 & $<---$ & Perceived Risk &, 370 \\
X2\#3 & $<---$ & Perceived Risk &, 589 \\
X2\#4 & $<---$ & Perceived Risk &, 441 \\
X2\#5 & $<---$ & Perceived Risk &, 851 \\
X2\#6 & $<---$ & Perceived Risk &, 805 \\
X3\#1 & $<---$ & Price &, 577 \\
X3\#2 & $<---$ & Price &, 507 \\
X3\#3 & $<---$ & Price &, 526 \\
X3\#4 & $<---$ & Price &, 720 \\
\hline
\end{tabular}

Sumber: Diolah oleh peneliti, 2021

Besar kuat dan lemahnya indikator-indikator untuk mencerminkan variabel latennya dapat dianalisis dengan menggunakan hasil confirmatory factor analysis. Tabel 3 diatas menunjukkan bahwa indikator dari masing-masing variabel sudah memiliki nilai standardized estimate yang dapat diterima secara signifikan dengan nilai Critical Ratio $(\mathrm{CR})>1,97$ dimana CR adalah identik dengan $t_{\text {hitung dalam regresi. Dengan }}$ demikian dapat disimpulkan bahwa variabel-variabel tersebut di atas secara signifikan merupakan dimensi-dimensi untuk mencerminka variabel-variabel laten.

b. Konstruk Endogen

Hasil dari Confirmatory Factor Analysis untuk konstruk endogen disajikan seperti pada Tabel 4 sebagai berikut :

Tabel 3. Standardized Regression Weights CFA Konstruk Endogen

\begin{tabular}{|lll|r|}
\hline & & & Estimate \\
\hline Y1\#1 & $<---$ & Attitude toward Purchasing &, 683 \\
Y1\#2 & $<---$ & Attitude toward Purchasing &, 564 \\
Y1\#4 & $<---$ & Attitude toward Purchasing &, 858 \\
Y1\#5 & $<---$ & Attitude toward Purchasing &, 803 \\
Y2\#1 & $<---$ & Purchase Intention &, 728 \\
Y2\#2 & $<---$ & Purchase Intention &, 721 \\
Y2\#3 & $<---$ & Purchase Intention &, 625 \\
Y2\#4 & $<---$ & Purchase Intention &, 409 \\
Y2\#5 & $<---$ & Purchase Intention &, 657 \\
Y3\#1 & $<---$ & Purchase Decision &, 560 \\
Y3\#2 & $<---$ & Purchase Decision &, 842 \\
\hline
\end{tabular}




\begin{tabular}{|lll|r|}
\hline & & & Estimate \\
\hline Y3\#3 & $<---$ & Purchase Decision &, 619 \\
Y3\#4 & $<---$ & Purchase Decision &, 616 \\
Y1\#3 & $<---$ & Attitude toward Purchasing &, 687 \\
\hline \multicolumn{3}{|c|}{ Sumber: Diolah oleh peneliti, 2021 } \\
\hline
\end{tabular}

Sumber: Diolah oleh peneliti, 2021

Besar kuat dan lemahnya indikator-indikator untuk mencerminkan variabel latennya dapat dianalisis sebagaimana tersaji dalam Tabel 4 di atas menunjukkan bahwa indikator dari masing-masing variabel sudah memiliki nilai standardized estimate yang dapat diterima secara signifikan dengan nilai Critical Ratio (CR) $\pm 1,96$ dimana

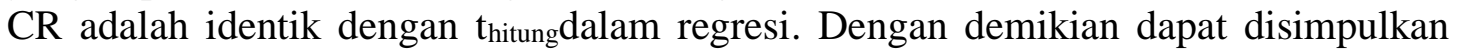
bahwa variabel-variabel tersebut di atas secara signifikan merupakan dimensi-dimensi dari variabel-variabel laten yang dibentuk.

\section{Hasil Uji Hipotesis}

Pembahasan hasil uji statistik dibuat berdasarkan angka-angka statistik uji AMOS terhadap kausalitas yang terjadi sebagai pembuktian hipotesis yang diangkat dalam penelitian ini sesuai dengan data yang digunakan dan kajian secara teoritis. Teori-teori ataupun hasil penelitian empirik tersebut mendukung, menolak atau bertentangan dengan hasil pengujian hipotesis yang dilakukan dalam penelitian serta akan dikemukakan pada keterbatasanketerbatasan yang dimiliki oleh penelitian ini.

Tabel 4. Estimasi Parameter Standardized Regression Weights

\begin{tabular}{|c|c|c|c|c|c|c|c|}
\hline & & & Estimate & S.E. & C.R. & $\mathbf{P}$ & Keterangan \\
\hline ATP & $<--$ & $\mathrm{SN}$ & 0,516 & 0,118 & 5,469 & 0,000 & Signifikan \\
\hline ATP & $<--$ & $\mathrm{P}$ & 0,478 & 0,114 & 4,694 & 0,000 & Signifikan \\
\hline ATP & $<--$ & PR & $-0,239$ & 0,138 & $-3,043$ & 0,002 & Signifikan \\
\hline PI & $<--$ & $\mathrm{SN}$ & 0,374 & 0,108 & 4,659 & 0,000 & Signifikan \\
\hline $\mathrm{PI}$ & $<--$ & PR & $-0,221$ & 0,129 & $-3,250$ & 0,001 & Signifikan \\
\hline $\mathrm{PI}$ & $<-$ & $\mathrm{P}$ & 0,186 & 0,085 & 2,641 & 0,008 & Signifikan \\
\hline PI & $<-$ & ATP & 0,558 & 0,104 & 5,813 & 0,000 & Signifikan \\
\hline $\mathrm{PD}$ & $<-$ & PI & 0,902 & 0,087 & 7,674 & 0,000 & Signifikan \\
\hline
\end{tabular}

Keterangan: SN (Subjective Norms); PR (Perceived Risk); P (Price); ATP (Attitude toward Purchasing); PI (Purchase Intention); PD (Purchase Decision)

Sumber : Data telah diolah oleh peneliti, 2021

\section{Pengaruh Subjective Norms terhadap Attitude toward Purchasing}

Berdasarkan hasil perhitungan koefisien parameter antara Subjective Norms terhadap Attitude toward Purchasing menunjukkan pengaruh signifikan. Indikator yang memiliki nilai Loading Factor terbesar dari variabel Subjective Norms adalah indikator Smart Decision yang memiliki arti bahwa variabel Subjective Norms tercermin pada indikator Smart Decision dan variabel yang dipengaruhi adalah variabel Attitude toward Purchasing yang tercermin pada indikator Better Choice (Pilihan Terbaik).Hasil penelitian ini juga mendukung wacana yang dilakukan oleh peneliti sebelumnya yang juga meneliti antar variabel Subjective Norms dan Attitude toward Purchasing yang dilakukan oleh Kim dan Karpova (2010), Albarq 
(2015), Riquelme et al. (2012), Hanzaee dan Taghipourian (2012) dan penelitian Chiu dan Leng (2015).

\section{Pengaruh Perceived Risk terhadap Attitude toward Purchasing}

Berdasarkan hasil perhitungan koefisien parameter antara Perceived Risk terhadap Attitude toward Purchasing menunjukkan pengaruh signifikan. Indikator yang memiliki nilai Loading Factor terbesar dari variabel Perceived Risk adalah indikator Psychological Risk yang memiliki arti bahwa variabel Perceived Risk tercermin pada indikator Psychological Risk dan variabel yang dipengaruhi adalah variabel Attitude toward Purchasing yang tercermin pada indikator Better Choice (Pilihan Terbaik).Hasil penelitian ini juga mendukung wacana yang dilakukan oleh peneliti sebelumnya yang juga meneliti antar variabel Perceived Risk dan Attitude toward Purchasing yang dilakukan oleh Hanzaee dan Taghipourian (2012), Albarq (2013) dan Mollahosseini et al. (2012).

\section{Pengaruh Price terhadap Attitude toward Purchasing}

Berdasarkan hasil perhitungan koefisien parameter antara Price terhadap Attitude toward Purchasing menunjukkan pengaruh signifikan. Indikator yang memiliki nilai Loading Factor terbesar dari variabel Price adalah indikator Cheapness yang memiliki arti bahwa variabel Price tercermin pada indikator Cheapness dan variabel yang dipengaruhi adalah variabel Attitude toward Purchasing yang tercermin pada indikator Better Choice (Pilihan Terbaik).Hasil penelitian ini juga mendukung wacana yang dilakukan oleh peneliti sebelumnya yang juga meneliti antar variabel Price dan Attitude toward Purchasing yang dilakukan oleh Mollahosseini et al. (2012), Huang et al.(2004) dan Chiu et. al (2014).

\section{Pengaruh Subjective Norms terhadap Purchase Intention}

Berdasarkan hasil perhitungan koefisien parameter antara Subjective Norms terhadap Purchase Intention menunjukkan pengaruh signifikan. Hasil penelitian ini juga mendukung wacana yang dilakukan oleh peneliti sebelumnya yang juga meneliti antar variabel Subjective Norms dan Purchase Intention yang dilakukan oleh Chiu dan Leng (2016) dan Kim dan Karpova (2010).

\section{Pengaruh Perceived Risk terhadap Purchase Intention}

Berdasarkan hasil perhitungan koefisien parameter antara Perceived Risk terhadap Purchase Intention menunjukkan pengaruh signifikan. Hasil penelitian ini juga mendukung wacana yang dilakukan oleh peneliti sebelumnya yang juga meneliti antar variabel Perceived Risk dan Purchase Intention yang dilakukan oleh Wang dan Chen (2016), Luo et al.(2010) dan Wang dan Chen (2016).

\section{Pengaruh Price terhadap Purchase Intention}

Berdasarkan hasil perhitungan koefisien parameter antara Price terhadap Purchase Intention menunjukkan pengaruh signifikan. Hasil penelitian ini juga mendukung wacana yang dilakukan oleh peneliti sebelumnya yang juga meneliti antar variabel Price dan Purchase Intention yang dilakukan oleh Mollahosseini et al. (2012), Huang et al.(2004) dan Chiu et. al (2014).

\section{Pengaruh Attitude toward Purchasing terhadap Purchase Intention}

Berdasarkan hasil perhitungan koefisien parameter antara Attitude toward Purchasing terhadap Purchase Intention menunjukkan pengaruh signifikan. Hasil penelitian ini juga mendukung wacana yang dilakukan oleh peneliti sebelumnya yang juga meneliti antar variabel Attitude toward Purchasing dan Purchase Intention yang dilakukan oleh Phau dan Teah (2009), Rahpeima et al. (2014) dan Wang et al (2005). 


\section{Pengaruh Purchase Intention terhadap Purchase Decision}

Berdasarkan hasil perhitungan koefisien parameter antara Purchase Intention terhadap Purchase Decision menunjukkan pengaruh signifikan. Hasil penelitian ini juga mendukung wacana yang dilakukan oleh peneliti sebelumnya yang juga meneliti antar variabel Purchase Decision dan Purchase Intention yang dilakukan oleh Rachbini (2018), Putra et al. (2016) dan Magfiroh et al. (2016)

\section{Kesimpulan}

Berdasarkan hasil pengujian hipotesis dapat diketahui bahwa antiseden dari Purchase Intention memiliki hubungan yang signifikan terhadap Purchase Decision Sepatu Non Original (KW) pada mahasiswa Perguruan Tinggi di Kota Samarinda, karena semua hipotesis yang diajukan terbuti diterima.

Keterbatasan penelitian ini terletak pada kendala waktu dan akses informasi kepada responden. Untuk mendapatkan model yang lebih komprehensif terkait dengan anteseden kinerja perangkat publik, diperlukan studi longitudinal dengan instrumen yang menangkap respons yang lebih terperinci dari responden yang lebih disukai yang memiliki kluster yang lebih homogen. Untuk peneliti selanjutnya disarankan untuk menambah ataupun mengganti variabel lain untuk mengetahui apakah ada faktor lain yang memicu keputusan pembelian Sepatu Non Original (KW)

\section{Daftar Pustaka}

Ajzen, I. (1991). The theory of planned behavior. Organizational Behavior and Human Decision Processes. https://doi.org/10.1016/0749-5978(91)90020-T

Ajzen, I. (2005). Attitudes, Personality and Behavior (Second Edition). McGraw-Hill Education (12th ed.). New York (NY): McGraw-Hill Education.

Albarq, A. N. (2015). Counterfeit Products and the Role of the Consumer in Saudi Arabia. American Journal of Industrial and Business Management, 05(12), 819-827. Retrieved from http://dx.doi.org/10.4236/ajibm.2015.512079

Amirullah. (2002). Perilaku Konsumen (Cetakan Pe). Jakarta: Graha Ilmu.

Assael, H. (1998). Consumer Behavior and Marketing Action (6th ed.). New York (NY): International Thomson Publishing.

Bauer, R. A. (1960). Consumer Behavior as Risk Taking. Journal of Business Research,2333.

Chiu, W., Lee, K., dan Won, D. (2014). Consumer Behavior Toward Counterfeit Sporting Goods. Society for Personality Research, 42(4), 615-624. Retrieved from http://dx.doi.org/10.2224/sbp.2014.42.4.615

Chiu, W., dan Leng, H. K. (2016). Consumers 'intention to purchase counterfeit sporting goods in Singapore and Taiwan. Asia Pacific Journal of Marketing and Logistics, 28(1), 23-36. https://doi.org/10.1108/APJML-02-2015-0031

Dowling, G. R., dan Staelin, R. (1994). A model of perceived risk and intended risk handling activity. Journal of Consumer Research, 21.

Engel dkk. 2002. Perilaku konsumen.Alih bahasa Drs. F.X. Budiyanto. Jakarta: Binarupa Aksara.

Fishbein, M., dan Ajzen, I. . (1991). Belief, Attitude, Intention, and Behavior: An Introduction to Theory and Research. Addison-Wesley: Reading, MA.

Gerungan, (2004). Psikologi Sosial. Bandung: Rafika Aditama

Grossman, G. M., dan Shapiro, C. (1998). No Title. Foreign Counterfeiting of Status Goods, (2), 79-100. 
Hair, J., J. F., Black, W. C., Babin, B. J., Anderson, R. E., dan Tatham, R. L. (2010). Multivariate Data Analysis (7th ed.). Upper Saddle River, NJ: Pearson Prentice Hall.

Hanzaee, K. H., dan Jalalian, S. (2012). Impact of Non-Price Factors on Purchase Intention Counterfeits. Research Journal of Applied Sciences, Engineering and Technology, 4(18), 3313-3322.

Huang, J., Lee, B. C. Y., dan Ho, S. H. (2004). Consumer attitude toward gray market goods. International Marketing Review, 21(6), 598-614. https://doi.org/10.1108/02651330410568033

Jacoby, J., dan Kaplan, L. B. (1972). The Components of Perceived Risk. Proceedings of the Annual Conference of the Association for Consumer Research, (10), 382-393.

Kim, H., dan Karpova, E. (2010). Consumer Attitudes Toward Fashion Counterfeits: Application of the Theory of Planned Behavior. Clothing dan Textiles Research Journa, (28 (2)), 79-94. https://doi.org/10.1177/0887302X09332513

Kotler, P., dan Armstrong, G. (2018). Principles of Marketing (17th ed.). United States: Pearson Education.

Kotler, P., dan Keller, K. L. (2015). Marketing Management 15/e. Prentice Hall. London: Pearson Education, Inc. https://doi.org/10.1177/1060028014534195

Machfoedz, M. (2005). Pengantar Pemasaran Modern. Yogyakarta: Upp Amp Ykpn.

Maghfiroh, A., Arifin, Z., dan Sunarti. (2016). Pengaruh Citra Merek Terhadap Minat Beli Dan Keputusan Pembelian (Survei pada Mahasiswa Program Studi Administrasi Binis Tahun Angkatan 2013/2014 Fakultas Ilmu Administrasi Universitas Brawijaya Malang Pembeli Indosat Ooredoo). Jurnal Administrasi Bisnis (JAB), 40(1), 132-140. https://doi.org/10.1016/j.fishres.2009.10.012

Matos, C. A., Cristiana, T. I., dan A.R., C. (2007). Consumer attitudes toward counterfeits: A review and extension. Journal of Consumer Marketing, 24(1), 36-47.

Mollahosseini, A., Karbasi, B. J., dan Sadeghi, Z. (2012). Investigating the Influential Factors on Purchase Intention the ' Gray Market' Goods in South-East of Iran. International Business and Management, Canadian Research dan Development Center of Sciences and Cultures, 4(1), 48-56. https://doi.org/10.3968/j.ibm.1923842820120401.1020

Peter, J. P., dan Olson, J. C. (2012). Consumer Behavior dan Marketing Strategy (9th ed.). New York (NY): McGraw-Hill Education.

Phau, I., dan Teah, M. (2009). luxury brands Devil wears ( counterfeit ) Prada: a study of antecedents and outcomes of attitudes towards counterfeits of luxury brands. Journal of Consumer Marketing, 26(1), 15-27. https://doi.org/10.1108/07363760910927019

Putra, E. W., Kumadji, S., dan Yulianto, E. (2016). Pengaruh Diskon Terhadap Minat Beli serta Dampaknya pada Keptusan Pembelian ( Study pada konsumen yang membeli produk diskon di Matahari Department Store Pasar Besar Malang ). Jurnal Administrasi Bisnis (JAB), 38(2), 184-193. Retrieved from administrasibisnis.studentjournal.ub.ac.id

Rachbini, W. (2018). The Impact of Consumer Trust, Perceived Risk, Perceived Benefit on Purchase Intention and Purchase Decision. International Journal of Advanced Research (IJAR), 6(1), 1036-1044. https://doi.org/10.21474/IJAR01/6317

Riquelme, H. E., Mahdi, E., Abbas, S., dan Rios, R. E. (2012). Intention to Purchase Fake Products in an Islamic Country. Education, Business and Society: Contemporary Middle Eastern Issues, 5(1), 6-22. https://doi.org/10.1108/17537981211225835

Schiffman, L. G., dan Kanuk, L. L. (2010). Consumer Behavior. New York (NY): Pearson Prentice Hall.

Sharma, P., dan Chan, R. Y. K. (2016). Demystifying Deliberate Counterfeit Purchase Behaviour towards A Unified Conceptual Framework. Marketing Intelligence dan Planning, 34(3), 318-335. 
Stanton, W. J. (1986). Prinsip Pemasaran. Jakarta: Erlangga.

Swastha, B. (2008). Menejemen Pemasaran Modern (2nd ed.). Yogyakarta: Liberty.

Tarkiainen, A., dan Sundqvist, S. (2005). Subjective norms, attitudes and intentions of Finnish consumers in buying organic food. British Food Journal, 107(11), 808-822. https://doi.org/10.1108/00070700510629760

Teik, D., Seng, T., dan Xin-Yi, A. (2015). To Buy or To Lie: Determinants of Purchase Intention of Counterfeit Fashion in Malaysia. International Conference on Marketing and Business Development Journal, 1(1), 49-56. Retrieved from http://search.proquest.com/pagepdf/1353258067/Record/B018E3B54EB244F1PQ/1?a ccountid=15920\#

Wang, Y. H., dan Chen, L. an. (2016). An Empirical Study of the Effect of Perceived Price on Purchase Intention Evidence from Low-Cost Carriers Department of Business Administration. International Journal of Business and Social Science, 7(4), 97-107. Retrieved from www.ijbssnet.com 